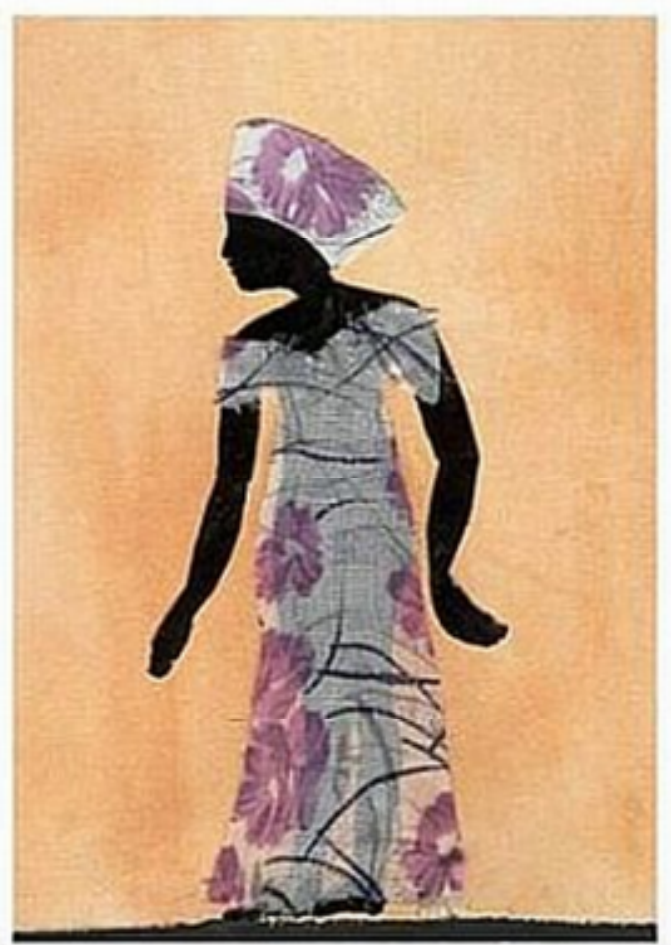

Ilustração Alessandra Threvenard

Cesária: inspirada em personagem criada por Clive Barker

\title{
Moçambique e Brasil: redes de leitura
}

\section{Adélio Dias}

por Anderson Higino

Adélio Dias é funcionário do Instituto Camões em Moçambique, mestrando em Ciência da Informação na Escola de Ciência da Informação da UFMG.

Anderson Higino é Bacharel em Física e especialista em Ensino de Ciências pela UFMG e Mestre em Educação Tecnológica pelo CEFET-MG, onde leciona Física nos cursos de Engenharia e Tecnologia. Atualmente, cursa o doutorado em Ciência da Informação na Escola de Ciência da Informação da UFMG, dedicando-se à investigação sobre transdisciplinaridade e, na Faculdade de Letras da UFMG, coordena o Fórum de Ensino de Leitura do Programa de Ensino, Pesquisa e Extensão A tela e o texto. 
Anderson Higino - Conte-nos sobre sua formação acadêmica e sua experiência profissional em Moçambique. Como se deu a decisão de dar seqüência aos estudos no Brasil?

Adélio Dias - Eu sou formado em Letras. Fiz a Licenciatura em Ensino de Português pela Universidade Pedagógica de Maputo. É um curso que nos habilita a lecionar no ensino secundário, pré-universitário e universitário. Após esse curso, a convite da minha professora, ingressei, como assistente, na Biblioteca do Instituto Camões, onde sou funcionário até a presente data. Fiz alguns cursos de capacitação na área de Documentação, para, no mínimo, conhecer os conceitos de Biblioteconomia. Nove anos depois, em virtude de ter ganho interesse pela área de biblioteconomia, candidatei-me à pós-graduação em Ciência da Informação, aqui no Brasil, através do Programa Estudantes Convênio, promovido pelo governo brasileiro, em cooperação com o governo de Moçambique.

Como são o quadro da alfabetização e o nível de leitura da população moçambicana no português, a língua do mesmo colonizador que também aportou em terras brasileiras? Qual o panorama atual de sobrevivência das línguas nativas?

Moçambique, como se sabe, é ex-colônia portuguesa e a colonização durou vários anos - a independência deu-se apenas em 1975. Uma das políticas do colonizador era a de não permitir ao moçambicano (preto) acesso à educação. As consequiências disso ainda se fazem sentir até hoje, porque, em apenas 30 anos da independência, ainda não atingimos o nível de alfabetização desejável. Só para se ter uma idéia, o censo de 1997 aponta como de apenas 8,8\% o índice total da população que fala a língua portuguesa, sendo de $6,5 \%$ da população que tem o português como língua materna. Recorde-se que a população de Moçambique é estimada em 19 milhões de habitantes. Neste momento, esforços estão sendo envidados no sentido de, no ensino oficial, alfabetizar-se o maior número possível de moçambicanos. No entanto, por decisão do governo, tomada a partir de pesquisa pedagógica, as línguas nacionais nativas entrarão, em simultâneo com o português, nas séries iniciais. Essa medida tem o sentido de encorajar e fazer com que as crianças, que têm o contacto com o português pela primeira vez, não se sintam retraídas e com desejo de abandonar a escola. Elas poderão adquirir muitas competências e habilidades, sobretudo a competência comunicativa em suas próprias línguas, em paralelo com o português.

Que comparação você pode fazer, no que se refere à alfabetização e à leitura em português, entre o cenário de Moçambique e o do Brasil? Quais as principais semelhanças e diferenças? 
A grande semelhança entre o vosso país e o meu é estarmos a ensinar/aprender a mesma língua - somos ambos membros da CPLP (Comunidade dos Países de Língua Portuguesa). As diferenças dão-se pelo facto de o Brasil possuir apenas o português como desafio para a alfabetização, o que, quanto a mim, torna a tarefa mais fácil. No caso moçambicano, em que maior percentagem da população não tem o português como língua-mãe, - processo de alfabetização em português torna-se mais difícil, comparando com a realidade brasileira. Mas não restam dúvidas de que os princípios pedagógicos das propostas e ações de incrementação do hábito da leitura sejam os mesmos que se mostram ideais para a alfabetização.

Que apreciação pessoal você faz sobre a convivência, em Moçambique, do cânone cultural e literário tradicional, baseado na oralidade, com o cânone do colonizador, baseado na língua escrita?

Considero tratar-se de uma convivência atualmente fácil - em decorrência de um processo histórico de conquista de espaço e, em geral, muito necessária, na medida em que não somente permite preservar a cultura local, como também enriquece 0 desenvolvimento intelectual do individuo. A literatura de cunho oral africana, contraposta à de cunho escrito do colonizador, faz com que se manifestem novas descobertas no universo da escrita. Aliás, muitos estudiosos, quer sejam europeus (portugueses), quer sejam africanos, escrevem muito sobre esse casamento, realçando tais factos. Por exemplo, os textos de Mia Couto são inteiramente caracterizados por uma língua que se poderia chamar um "português-moçambicano", na qual expressões estranhas ao português europeu são a ele integradas, produzindo efeitos estilísticos de grande riqueza.

Como você percebe, na literatura de Moçambique, a relação entre $o$ cânone $e$ as inovações? Que novas possibilidades têm sido exploradas pelos escritores de seu país?

Os escritores africanos, no geral, e moçambicanos, em particular, procuram, embora não seja a preocupação principal, conciliar a linguagem oral com as regras da escrita. Cerca de 90\% da literatura produzida em Moçambique é caracterizada pelo cunho oral, ou seja, pela inserção de muitas expressões típicas da zona a que a história se refere, e isso traz o tal efeito do real de que Roland Barthes fala na sua obra intitulada "O efeito do real". Expressões de cunho oral dão uma certa verossimilhança à historia. Portanto, sinto que os escritores moçambicanos não se preocupam com a maneira de escrever dos europeus; preocupam-se, sim, com o "tirar" para fora o que lhes vem na alma. E isso dá um sabor especial ao texto. 
Que possibilidades você observa, em Moçambique, para ações locais de incentivo à leitura? Vislumbra algum tipo possível de intercâmbio entre iniciativas desenvolvidas aqui e lá?

Uma coisa que eu sempre sonhei desde que cá cheguei, e até um pouco relacionada com o meu projecto de pesquisa, é a promoção das bibliotecas rurais e/ou escolares. Por exemplo, o CarroBiblioteca, iniciativa da Escola de Ciência de Informação da UFMG, penso que é um óptimo recurso para abarcar o maior número possível de cidadãos, através de pequenas actividades de incentivo à leitura. Penso que é uma estratégia boa para esse fim. 